\title{
Cząsteczki mikroRNA jako istotny składnik mechanizmów regulacji ekspresji genów związanych z nowotworami
}

\author{
Michał Budzyński, Anna Grenda, Agata A. Filip
}

W niniejszej pracy przedstawiono zależności pomiędzy zmianami w ekspresji poszczególnych mikroRNA a powstawaniem i rozwojem wybranych nowotworów. Dokonano przeglądu doniesień na temat użyteczności badań nad ekspresją mikroRNA, które w przyszłości mogą być wartościowymi i pożądanymi przez diagnostów i lekarzy wskaźnikami prognostycznymi i predykcyjnymi. Mogą się one stać podwaliną do opracowania nowych metod leczniczych z wykorzystaniem antysensownych miRNA (antagomiry) czy leków mających na celu kompensację ilości cząsteczek w przypadku delecji lub uszkodzeń genów dla konkretnych mikroRNA. Dałoby to potencjalną możliwość regulacji ekspresji genów o znaczeniu strategicznym w procesach związanych z powstawaniem i rozwojem nowotworów.

\section{MicroRNA molecules as a significant constituent in gene regulation mechanisms related to cancer}

This paper presents the relationship between changes in the expression of specific microRNAs and the formation and development of selected cancers. An overview of reportsis provided on the usefulness of research on microRNA expression, which in the future may become valuable and desirable prognostic and prediction factors for diagnosticians and clinicians. miRNA will presumably become the cornerstone for the development of new therapeutic approaches using antisense miRNAs (antagomirs) or drugs aimed at miRNA offsetting in the case of deletion or damage to their genes. It would offer the potential possibility of the regulation of gene expression which is of great significance for the origin and development of cancers.

NOWOTWORY Journal of Oncology 2014; 64, 1: 48-60

Słowa kluczowe: mikroRNA, nowotwory, profil ekspresji miRNA, regulacja ekspresji genów

Key words: microRNAs, cancer, miRNA expression profile, gene expression regulation

\section{Wstęp}

MikroRNA to krótkie, niekodujące, jednoniciowe cząsteczki biorące udział w regulacji ekspresji genów. Tworzone są z dwuniciowych prekursorów, powstałych przy udziale polimerazy RNA II. Dojrzałe cząsteczki miRNA liczą 19-23 nukleotydów i są wbudowywane w kompleksy wyciszające translację (RNA-induced silencing complex, miRISC). Kompleksy te dzięki cząsteczce miRNA mają zdolność przyłączania się do regionów 3'UTR (untranslated regions) mRNA genu docelowego i w wyniku pełnej komplementarności nukleotydowej mogą prowadzić do degradacji transkryptu. Jest to możliwe dzięki białkom Ago (Argonaute) wchodzącym w skład RISC, które wykazują aktywność endonukleolityczną. Jednak w większości przypadków mikroRNA nie wykazuje całkowitej komplementarności do 3'UTR. Skutkuje to zahamowaniem translacji docelowego mRNA [1] (ryc. 1).

Cząsteczki mikroRNA biorą udział w procesach kluczowych dla rozwoju i funkcjonowania organizmu, takich jak podziały komórkowe, różnicowanie i programowana śmierć komórek, powstawanie naczyń krwionośnych czy nowo- 


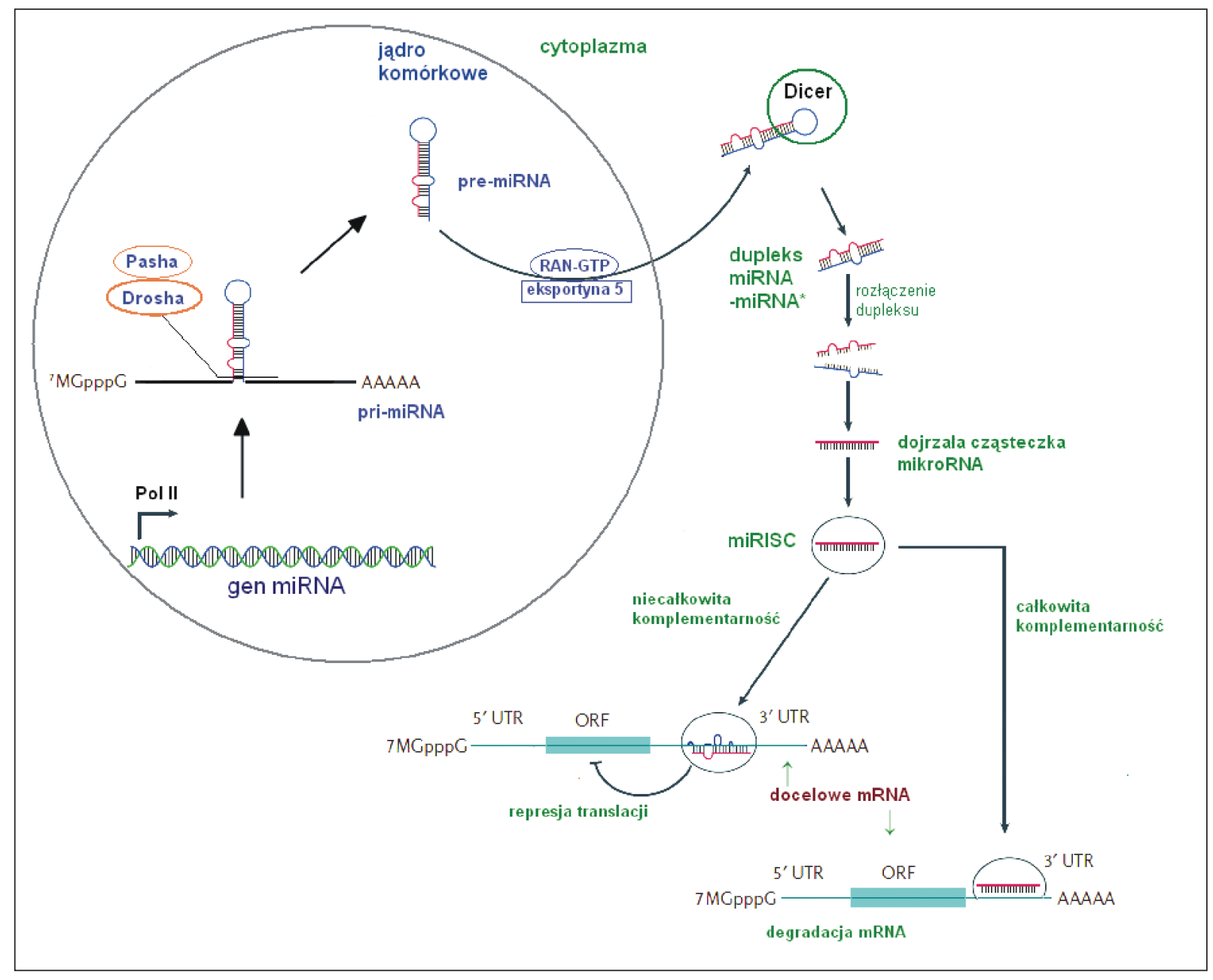

Rycina 1. Mechanizm powstawania i działania cząsteczek mikroRNA (za Kerscher i Slack 2006, modyfikacja) [4]. Po transkrypcji genów mikroRNA powstają pierwotne transkrypty pri-miRNA o długości około 70 nukleotydów, posiadające czapeczkę oraz ogon poliA. Są one poddawane obróbce przez enzym Drosha o aktywności RNazylll (kofaktor Pasha u bezkręgowców) i generowane są pre-miRNA. Transportowane są one do cytoplazmy przez Eksportyny 5, które współdziałają z białkiem RAN zależnym od GTP. Następnie enzym Dicer o właściwościach RNazylll przycina pre-miRNA, w wyniku czego powstają dupleksy miRNA-miRNA* (nić wiodąca i pasażerska oznaczona gwiazdką). Dupleks jest wbudowywany w kompleksy miRISC zawierające białka Ago. Najczęściej jako funkcjonalna wybierana jest nić wiodąca, przy czym udowodniono, że również nić pasażerska może brać udział w regulacji ekspresji i nie zawsze podlega ona degradacji. Odpowiednia nić mikroRNA jest komplementarna do docelowego mRNA, przez co bierze udział w negatywnej regulacji ekspresji genów na poziomie potranskrypcyjnym. Możliwe są dwie drogi działania miRNA w zależności od stopnia komplementarności miRNA do mRNA. W przypadku całkowitej (lub prawie całkowitej) zgodności nukleotydowej mikroRNA może indukować degradację mRNA [4]

tworzenie [2]. Ze względu na możliwość regulacji ekspresji genów na poziomie potranskrypcyjnym mikroRNA wpływają docelowo na ilość poszczególnych białek w organizmie. Można powiedzieć, że mikroRNA są „strażnikami" dbającymi o prawidłowy przebieg procesów w komórce. Ekspresja ponad 30\% genów ludzkich jest kontrolowana przez miRNA.

Wykazano, że geny dla mikroRNA często zlokalizowane są w miejscach łamliwych chromosomów (fragile sites) lub w ich pobliżu [3]. W efekcie uszkodzeń genomu, takich jak translokacje, delecje, amplifikacje, integracje obcego DNA, np. wirusa HPV (human papilloma virus) wpływają nie tylko na ekspresję genów białek będących supresorami nowotworzenia (tumor suppressor - TS), ale również na ekspresję
mikroRNA. Zmiana poziomu ekspresji tych ostatnich jest obserwowana w różnego rodzaju nowotworach [3]. Różnorodność genów regulowanych przez miRNA sprawia, że w kontekście rozwoju nowotworu cząsteczki te mogą zachowywać się jak onkogeny i jak supresory transformacji (ryc. 2, 3).

Na podstawie poziomu ekspresji miRNA można różnicować tkanki prawidłowe od zmienionych nowotworowo. Profilowanie ekspresji mikroRNA może być dobrym narzędziem diagnostycznym do oceny stopnia zaawansowania choroby czy szacowania czasu przeżycia, a także może być pomocne przy wyborze leczenia dostosowanego do indywidualnych potrzeb chorego. 


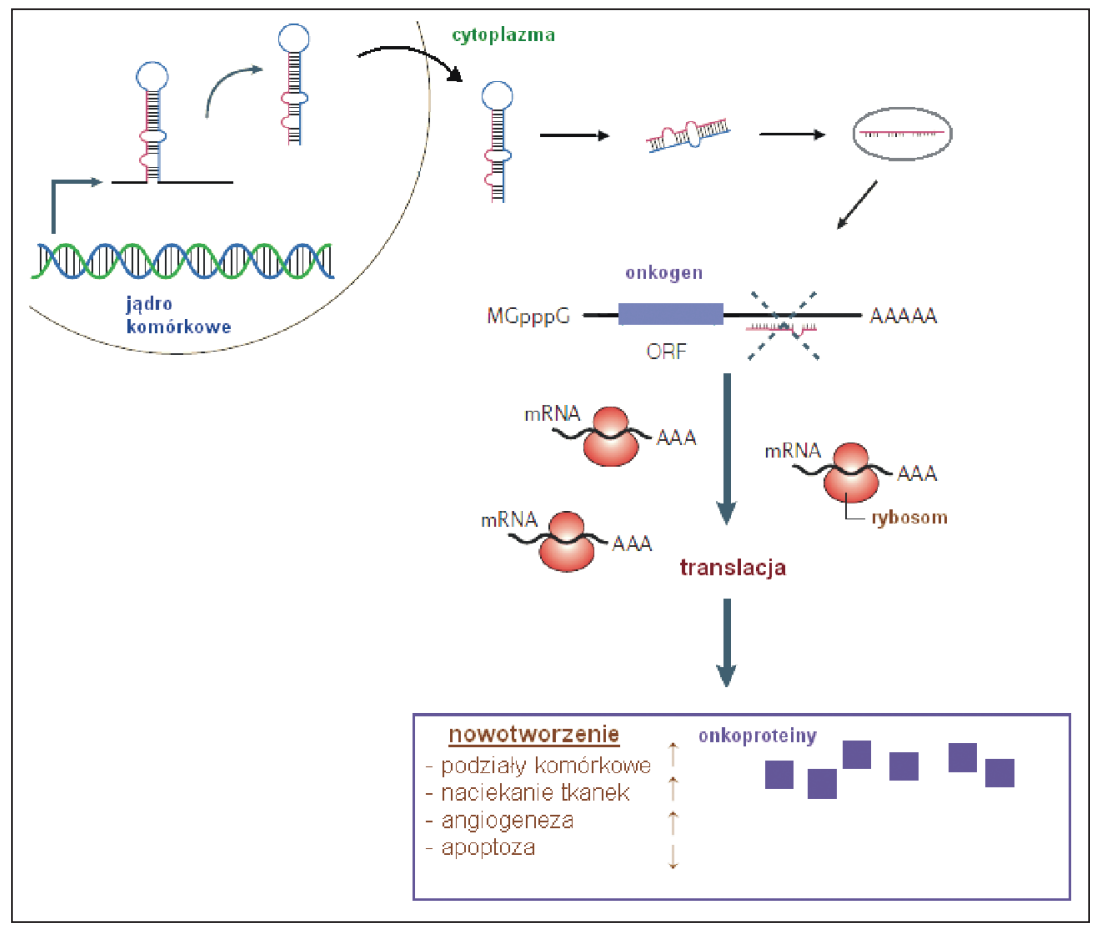

Rycina 2. MikroRNA funkcjonujące jako supresory nowotworów (za Kerscher i Slack 2006, modyfikacja) [4]. Delecja genów mikroRNA funkcjonujących jako supresory nowotworów lub zmniejszenie poziomu ich ekspresji może prowadzić do nowotworzenia. Obniżony poziom ekspresji mikroRNA może być spowodowany zaburzeniami na każdym z etapów biogenezy

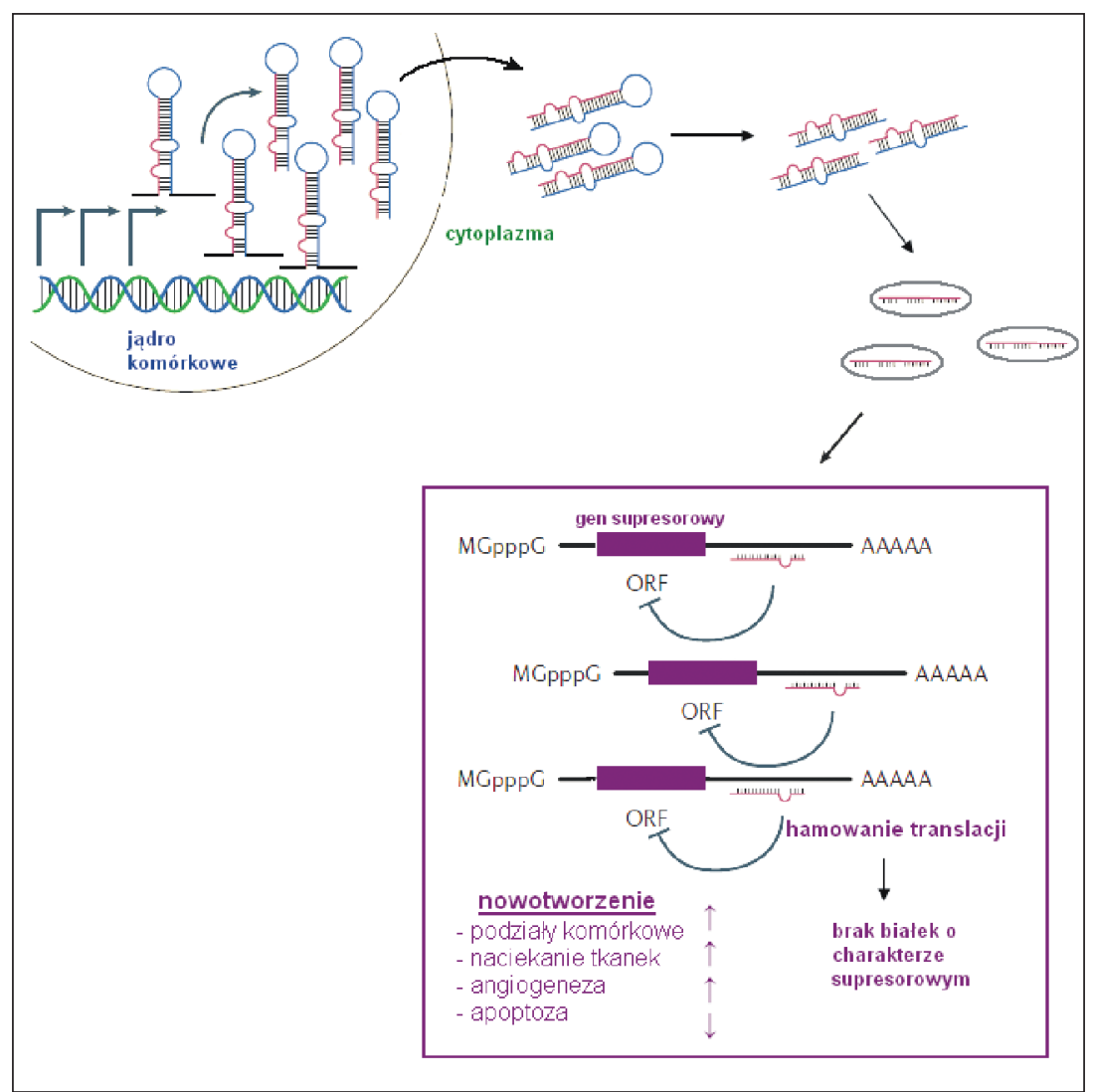

Rycina 3. MikroRNA funkcjonujące jako onkogeny (za Kerscher i Slack 2006, modyfikacja) [4]. Amplifikacja genów dla mikroRNA funkcjonujących jako onkogeny (onkomiry) lub ich nadekspresja może prowadzić do nowotworzenia. Zwiększona ilość cząsteczek miRNA może być obserwowana w tkankach, które nie są charakterystyczne dla danego mikroRNA, czy we właściwych tkankach, ale w niewłaściwym czasie. W takiej sytuacji hamowana jest translacja docelowego mRNA dla białka będącego supresorem nowotworu. Może to być związane nie tylko z amplifikacją genów miRNA ale również z konstytutywną aktywnością ich regionów promotorowych, zwiększoną wydajnością procesów biogenezy czy zwiększoną stabilnością cząsteczek miRNA na każdym z etapów powstawania i dojrzewania cząsteczek 


\section{Charakterystyczny wzór ekspresji mikroRNA w określonym typie nowotworu Nowotwory płuca}

Wczesne wykrycie nowotworów płuca jest uważane za czynnik krytyczny w ich leczeniu. Określenie poziomu ekspresji poszczególnych mikroRNA oraz badanie zależności między profilami ekspresji tych cząsteczek a przeżyciem chorych może w przyszłości być pomocne przy wczesnym wykrywaniu nowotworów płuca oraz prognozowaniu przebiegu choroby (tab. I - tylko w wersji elektronicznej artykułu).

Przeprowadzone w ostatnich latach badania wykazały, że cząsteczki z rodziny miR-183 (mikroRNA-96/182/183) wykazują wysoki poziom ekspresji zarówno w surowicy, jak i w komórkach nowotworowych u chorych z niedrobnokomórkowym rakiem płuca (non-small-cell lung carcinoma, NSCLC) [5]. Ponadto nadekspresja miR-96 jest porównywalna w surowicy i w tkance guza. Z badań wynika, że nadekspresja miR-183 wiąże się z przerzutami do węzłów chłonnych oraz z postępem choroby. Zauważono również, że zwiększona ilość mikroRNA-182 związana jest z przyspieszeniem wzrostu guza. Nadekspresja cząsteczek z rodziny mikroRNA-183 odgrywa znaczącą rolę w zahamowaniu apoptozy, wzroście guza, naciekaniu sąsiednich tkanek przez komórki nowotworowe czy przerzutowaniu, i z tego względu można zaliczyć je do onkogenów (onkomirów) [5].

Na onkogenną rolę miR-183 wskazują również Sarver i Subramanian [6]. Przypuszczają oni, że rola tej cząsteczki może być związana z procesami migracji komórek, a jej zwiększona ilość w wielu typach nowotworów może znosić ekspresję dwóch supresorów nowotworów: EGR1 (early growth response 1) i PTEN (phosphatase and tensin homolog) [6]. Cząsteczki z rodziny miR-183 mogą w przyszłości posłużyć do przewidywania czasu przeżycia chorych z NSCLC, ponieważ nadekspresja mikroRNA-96/182/183 w guzach jak i w surowicy ma związek ze skróconym czasem przeżycia [5]. Konieczne jednak są badania dużej grupy chorych, pozwalające określić znaczenie mikroRNA-183 w prognozowaniu przebiegu choroby czy określaniu stadium jej zaawansowania.

Rola mikroRNA-183 w nowotworach płuca nie jest do końca poznana. Wang i wsp. przeprowadzili badania z wykorzystaniem linii komórkowych raka płuca 801D oraz 95C, wyprowadzonych ze specyficznego rodzaju nowotworu, tj. guza płuca olbrzymiokomórkowego (pulmonary giant cell carcinoma), który charakteryzuje się znacznym poziomem złośliwości, co związane jest z dużą zdolnością komórek do migracji i naciekania tkanek [7]. Stwierdzono niską ekspresję miR-183 w linii 801D, mającej większy potencjał przerzutowy, i udowodniono, że suplementacja mikroRNA-183 na drodze transfekcji zmniejsza migrację komórek, nie ma wpływu natomiast na proces apoptozy [7]. Jednym z genów docelowych dla miR-183 jest VIL2, kodujący białko ezrynę, zaangażowaną m.in. w mobilność, adhezję oraz organizację cytoszkieletu komórek [8]. Linia 801D charakteryzuje się wysoką ekspresją VIL2, która po transfekcji miR-183 ulega zniesieniu. Sugeruje się zatem, że ta cząsteczka mikroRNA ma duże znaczenie w procesach związanych z przerzutowaniem i mogłaby stanowić nowy cel terapii [7].

W komórkach NSCLC obserwowana jest obniżona ekspresja miRNA-451. Wykazano, że ma to związek z przerzutami do węzłów chłonnych oraz stopniem zaawansowania klinicznego choroby [9]. Niska ekspresja miR-451 wiąże się ze złym rokowaniem oraz skróconym czasem przeżycia. Istotne są również znaczne różnice w profilach ekspresji tej cząsteczki u chorych palących i niepalących. W obu przypadkach jest ona obniżona, jednak większy spadek obserwowany jest u osób palących. Sugeruje się więc, że palenie tytoniu, profil ekspresji miRNA-451 oraz obecność lokalnych przerzutów NSCLC mogą wspólnie posłużyć jako niezależny czynnik prognostyczny wskazujący na gorsze rokowanie dla chorych na niedrobnokomórkowego raka płuca [9].

Badania na liniach komórkowych, w których wymuszono ekspresję mikroRNA-451, wykazały, że cząsteczka ta bierze udział w hamowaniu wzrostu guza przez zatrzymywanie cyklu komórkowego w fazie G1. Ponadto komórki z wymuszoną ekspresją miR-451 mają mniejszą zdolność do naciekania sąsiednich tkanek. Wskazuje się również na możliwość ich udziału w indukcji apoptozy poprzez inaktywację ścieżek sygnalizacyjnych kinazy AKT ( $v$-akt murine thymoma viral oncogene homolog) [9]. miR-451 posiada właściwości supresorowe, co najprawdopodobniej wiąże się z możliwością wyciszania RAB14 (RAS-related protein 14). Spadek ekspresji mikroRNA-451 może skutkować zwiększoną ilością białka RAB14, a jego udział w rekrutacji kolejnych białek efektorowych szlaków sygnalizacyjnych prawdopodobnie ułatwia komórkom nowotworowym przemieszczanie się i naciekanie tkanek [10].

Guzy w płucach (solitary pulmonary nodule) są wykrywane zzastosowaniem m.in. tomografii komputerowej. Być może uzupełnieniem diagnostyki zmian nowotworowych będzie określenie profilu ekspresji wybranych cząsteczek mikroRNA w osoczu. Badania wykazały, że u osób z niezłośliwymi jak i złośliwymi guzami w płucach widoczna jest nadekspresja miR-21 i miR-210 [11]. Ponadto zauważono, że ich ekspresja u chorych z guzem złośliwym jest wyższa w porównaniu z osobami ze zmianą łagodną. Inną cząsteczką, której zaburzenie ekspresji jest związane z występowaniem nowotworów płuca jest mikroRNA-486-5p. Obniżona ekspresja tego mikroRNA obserwowana jest zarówno u osób ze złośliwym, jak i niezłośliwym guzem płuca, przy czym w pierwszym przypadku jest znacznie niższa. Można zatem spekulować, że profile ekspresji miRNA będą stanowiły uzupełnienie diagnostyki mającej na celu odróżnienie tkanek ze złośliwymi zmianami od guzów łagodnych [11]. 


\section{Rak prostaty}

Jedną z najistotniejszych w rozwoju raka prostaty cząsteczek mikroRNA jest miR-21. Badania wykazały jej wzmożoną ekspresję w komórkach prostaty zmienionych nowotworowo. miR-21 może się przyczyniać do rozrostu guza, jak również ma wpływ na ruchliwość komórek nowotworowych, naciekanie naczyń krwionośnych i przerzutowanie. Jest to związane z możliwością wyciszania przez mikroRNA-21 takich genów, jak: PDCD4 (programmed cell death protein 4), TPM1 (tropomyosin alpha-1) i MARKCS (myristoylated alanine-rich protein kinase C substrate) [12]. Wydaje się więc, że terapia wykorzystująca cząsteczki antagonistyczne dla miR-21 (antagomiry) jest godnym uwagi celem badań, ponieważ mogłaby stanowić w przyszłości alternatywną drogę leczenia dla chorych z androgenoniezależnym rakiem prostaty, u których w większości przypadków obserwuje się nadekspresję cząsteczek mikroRNA-21 [12].

Badania na liniach komórkowych raka prostaty wykazały obniżoną ekspresję mikroRNA-330. Cząsteczka ta jest prawdopodobnie supresorem nowotworu dzięki zdolności wyciszania genów E2F1 (czynnik transkrypcyjny). Niska ekspresja miR-330 koreluje z wysokim poziomem E2F1 w komórkach nowotworowych, co może przyczyniać się do szybszego ich wzrostu w związku ze stymulacją transkrypcji genów zaangażowanych w ten proces [13]. Przy wymuszeniu ekspresji mikroRNA-330 w komórkach raka prostaty obserwowano zahamowanie wzrostu, co mogło być spowodowane redukcją ilości czynnika E2F1. Procesy te powiązane są najprawdopodobniej ze ścieżkami sygnalizacyjnymi kinazy AKT. Zwiększenie poziomu ekspresji miR-330 związane jest także z indukcją apoptozy. Wnioskuje się zatem, że miR-330 jest supresorem nowotworu, którego ekspresja w przypadku raka prostaty zostaje obniżona [13].

Wykazano, że ekspresja miR-141, miR-200b i miR-200c jest z łatwością wykrywana w komórkach nabłonka, natomiast jej brak był obserwowany w komórkach podstawnych prostaty [14]. Ze względu na to, że rak prostaty jest typem nowotworu wywodzącym się z komórek nabłonkowych, sugeruje się, że profilowanie krążących mikroRNA może ułatwić wykrywanie nowotworów prostaty. Zwraca się uwagę między innymi na cząsteczkę miR-141, która jest charakterystyczna dla komórek nabłonkowych. Poziom ekspresji może być określany na podstawie analizy krwi obwodowej, ponieważ cząsteczki mikroRNA uwalniane są do krwiobiegu i obecne zarówno w surowicy, jak i w osoczu [14]. Badanie ekspresji mikroRNA-141 ma zatem potencjał diagnostyczny przy wczesnym wykrywaniu nowotworu, ponieważ zaburzenie ekspresji miRNA można obserwować już w początkowym stadium choroby, a ocena krążących miRNA wydaje się być ułatwiona ze względu na mniej skomplikowane, w porównaniu z biopsją tkanki, pozyskiwanie materiału do badań [14].

\section{Nowotwory trzustki}

Rak trzustki (pancreatic cancer - PCa) jest jednym z najgorzej rokujących guzów litych, ze względu na późne zazwyczaj rozpoznanie i brak skutecznej terapii. Identyfikacja markerów charakterystycznych dla poszczególnych fenotypów nowotworowych jest strategiczna dla wczesnej diagnozy i stosowania skutecznych metod terapeutycznych.

W komórkach raka trzustki obserwuje się wzmożoną ekspresję genu dla mucyny 4 (MUC4 - cell surface associated, mucin 4). Wiąże się to ze zwiększoną ruchliwością komórek nowotworowych i ich zdolnością do naciekania tkanek i przerzutowania [15]. Jest to prawdopodobnie powiązane zobniżonym poziomem ekspresji miR-150 w komórkach raka trzustki, ponieważzauważono odwrotną korelację pomiędzy ilością białka MUC4 a poziomem ekspresji mikroRNA-150. Analiza komputerowa wykazała, że MUC4 może być genem docelowym dla cząsteczki miR-150, która przypuszczalnie jest supresorem nowotworu [15].

mikroRNA-150 wywiera wpływ również na ekspresję HER2 (human epidermal growth factor receptor 2). Wykazano, że wymuszenie ekspresji miR-150 w komórkach raka trzustki prowadzi do obniżenia ekspresji receptorów HER2, jak również poziomu ich fosforylacji. Wykazano także, że transfekcja cząsteczek miR-150 do komórek nowotworowych hamuje ich zdolność do tworzenia klonów, migracji i naciekania tkanek, wzmaga natomiast adhezję międzykomórkową [15].

Cząsteczka miRNA-21 funkcjonuje jako onkogen w przebiegu gruczolakoraka trzustki i w znacznej liczbie przypadków chorych obserwowana jest jej nadekspresja, co jest związane z wystąpieniem przerzutów do węzłów chłonnych oraz gorszym rokowaniem [16].

miRNA-21 może mieć wpływ na powstawanie i rozwój agresywnego typu przewodowego gruczolakoraka trzustki. miR-21 wykazuje potencjał wyciszania takich genów, jak Czynnik programowanej śmierci komórki 4 [PDCD4 - programmed cell death 4 (neoplastic transformation inhibitor)] czy tkankowy inhibitor metaloproteinazy (TIMP3, TIMP metallopeptidase inhibitor 3), przez co przebieg choroby może być znacznie agresywniejszy [16]. Zniesienie ekspresji PDCD4 w wyniku nadekspresji miR-21 powoduje zahamowanie stymulacji działania supresorów nowotworowych, takich jak TP53, kinaz cyklinozależnych czy urokinazowego receptora plazminogenu (u-PAR - urokinase plasminogen activator receptor). Może to prowadzić do zmniejszenia stopnia kontroli cyklu oraz różnicowania komórkowego, do zahamowania apoptozy, zbyt intensywnych podziałów komórkowych, a w konsekwencji do tworzenia przerzutów i postępu choroby [17].

Zniesienie ekspresji TIMP3 przez miR-21 może być jedną z przyczyn rozrostu guza oraz nabywania przez komórki zdolności do przerzutowania. Aby komórki nowotworowe mogły wydostać się z guza do krwiobiegu czy naczyń limfa- 
tycznych i dotrzeć do innych tkanek, muszą pokonać błony podstawne i struktury tkankowo-komórkowe, utworzone między innymi z kolagenu. Procesy te są ułatwione dzięki aktywności zewnątrzkomórkowej metaloproteinazy (MMP - matrix metallopeptidase). Wyciszenie ekspresji inhibitora metaloproteinaz (TIMP) prowadzi do zwiększenia ich aktywności, co ułatwia powstawanie odległych przerzutów [18].

CA 19-9 jest jednym z markerów surowiczych, którego ocena wykorzystywana jest w diagnostyce raka trzustki. Jest on jednak mało swoisty przez niespecyficzną ekspresję w łagodnych i złośliwych nowotworach, co może dawać fałszywie pozytywne i fałszywie negatywne wyniki [19]. Połączenie dwóch strategii badawczych, tj. identyfikacji profilu ekspresji wybranych krążących miRNA oraz badania poziomu CA 19-9 może być skuteczniejsze w diagnostyce nowotworów w początkowych stadiach choroby. miR-16 i miR-196a zostały wybrane spośród wielu mikroRNA, ponieważ wykazują potencjał diagnostyczny w związku z nadekspresją w komórkach raka trzustki [20]. Dzięki ocenie ekspresji tych dwu mikroRNA można różnicować chorych z PCa oraz osoby z przewlekłym zapaleniem trzustki. Jest to bardzo ważne ze względu na możliwość szybkiego diagnozowania choroby oraz doboru najwłaściwszego leczenia [20].

miR-34a oraz miR-143/145 wykazują obniżony poziom ekspresji w większości przypadków raka trzustki [21]. Przeprowadzono badania z wykorzystaniem mysich ksenograftów, które miały wyindukowane guzy podskórne o właściwościach nowotworów trzustki. Charakteryzowała je obniżona ekspresja mikroRNA-34a oraz mikroRNA-143/145. Wprowadzenie do ich komórek wektorów plazmidowych z wbudowanymi cząsteczkami mikroRNA doprowadziło do zahamowania wzrostu guzów PCa, podwyższenia poziomu apoptozy oraz zmniejszenia zdolności proliferacyjnych komórek nowotworowych [21]. Stało się tak zarówno dzięki zdolności miR-143/145 do wyciszania transkryptów KRAS2 (V-Ki-ras2 Kirsten rat sarcoma viral oncogene homolog), jak też zaangażowaniu miR-34a w procesy związane z funkcjonowaniem białka TP53. Być może dalsze badania pozwolą doskonalić tę strategię i będzie ona stosowana w przyszłości jako alternatywa dla tradycyjnych terapii [21].

\section{Rak żołądka}

Jednym z ważniejszych miRNA w patogenezie i przebiegu raka żołądka jest miR-148a. W komórkach nowotworu żołądka obserwowana jest obniżona ekspresja tej cząsteczki, co jest związane ze skróceniem czasu przeżycia chorych [22]. Sugeruje się, że mikroRNA-148a może być pomocna w diagnostyce tego nowotworu oraz przy szacowaniu czasu przeżycia.

Tseng i wsp. wskazują na złożoność procesów, w jakich uczestniczą miRNA, i podkreślają, że zmiany w ich ekspresji mogą prowadzić do szeregu zaburzeń w funkcjonowaniu komórki [22]. Wykazano, że nieprawidłowa ekspresja jed- nego mikroRNA może przyczyniać się do zaburzenia wielu procesów komórkowych tak, że w konsekwencji dochodzi do rozwoju nowotworów. Prawdopodobnie jest to związane z komplementarnością miRNA jednego typu do wielu różnych transkryptów. Przykładem jest mikroRNA-148a, posiadająca zdolność wyciszania takich onkogenów, jak Czynnik koagulujący PAl-1 (plasminogen activator inhibitor-1), czynnik adhezyjny ITGB8 (integrin, beta 8) czy gen białka zaangażowanego w ścieżki sygnalizacyjne związane z integrynami ITGA5 [integrin, alpha 5 (fibronectin receptor, alpha polypeptide)]. Działanie tych onkoprotein może zaburzać funkcjonowanie integryn i macierzy komórkowej. Obniżenie ekspresji miR-148a, i w następstwie naruszenie prawidłowej regulacji onkogenów, prowadzi do serii zdarzeń komórkowych, w których biorą udział liczne białka, których transkrypty są regulowane przez różne cząsteczki mikroRNA. Zatem procesy, w których uczestniczą cząsteczki miRNA, mogą tworzyć swoistą sieć interakcji w komórce, a zakłócenie jej funkcjonowania może przyczyniać się do przekształcenia komórek prawidłowych w nowotworowe [22].

Poza ITGA5 i ITGB8 genami docelowymi dla miR-148a są m.in. LRP2 (Iow density lipoprotein receptor-related protein 2), SERPINE1 (serpin peptidase inhibitor), NARG1 (N(alpha)-acetyltransferase 15), MTA2 (metastasis associated 1 family, member 2), TGF2 (transforming growth factor 2) [22]. Produkty tych genów tworzą sieć interakcji zaangażowanych w prawidłowe działanie cytoszkieletu, komunikację międzykomórkową, podziały komórkowe, angiogenezę czy kontrolę cyklu komórkowego. Regulując ekspresję genu dla integryny 5 miR-148a pośrednio wpływa na działanie białka FLT4 (fms-related tyrosine kinase 4), zaangażowanego w powstawanie nowych naczyń krwionośnych. Z kolei FLT4 wchodzi w interakcje z integryną 1, współdziałającą z integryną 5 [22]. Takie sieci zależności mogą być bardzo skomplikowane i angażować wiele białek, których transkrypty są regulowane przez różne cząsteczki miRNA.

MikroRNA-148a bierze także udział w kontroli podziałów komórkowych, działając na transkrypt genu CDKN1B (cyclin-dependent kinase inhibitor 1B). Produkt tego genu — białko P27 - jest kluczowym inhibitorem cyklu komórkowego. Wyłączenie ekspresji miR-148a w liniach komórkowych raka żołądka hamuje cykl komórkowy. Z kolei nadekspresja mikroRNA-148a prowadzi do progresji cyklu [23]. Co ciekawe, w komórkach raka żołądka w zaawansowanym stadium zaobserwowano znaczne obniżenie ekspresji miR-148a. Wskazuje to na złożoność procesów, w których biorą udział te cząsteczki miRNA [23].

U chorych na raka żołądka przerzuty do węzłów chłonnych oraz naciekanie naczyń krwionośnych przez komórki nowotworowe może być związane z obniżoną ekspresją miR-146a. Celem mikroRNA-146a są transkrypty EGFR (epidermal growth factor receptor) oraz IRAK1 (interleukin-1 receptor-associated kinase 1) [24]. 
Kolejnym mikroRNA, który ma znaczenie w rozwoju raka żołądka, jest mikroRNA-449. Dowiedziono, że ekspresja miR449 jest obniżona w komórkach nowotworu, a bezpośrednie cele molekularne tej cząsteczki to transkrypty GMNN (geminin DNA replication inhibitor), MET (metproto-oncogene, hepatocyte growth factor receptor), CCNE2 (cyclin E2), SIRT1 (sirtuin 1) i CDK6 (cyclin-dependent kinase 6). mikroRNA-449 może również brać udział w procesach związanych ze starzeniem się komórek oraz ich apoptozą poprzez aktywację szlaku białka TP53 (tumor protein p53). Obniżenie ekspresji miR-449 może być jedną z przyczyn przekształcania się komórek prawidłowych w nowotworowe [25].

Cząsteczkami, które wykazują nadekspresję w przypadku raka żołądka (GC — gastric cancer) — w porównaniu z komórkami niezmienionymi nowotworowo (NS - non-neoplastic stomach) - są mikroRNA-192 oraz mikroRNA-215. Wykazują one wzmożoną ekspresję in vivo i prawdopodobnie promują wzrost komórek oraz ich migrację. Sugeruje się, że miR-215 potranskrypcyjnie hamuje ekspresję ALCAM (activated leukocyte cell adhesion molecule), ponieważ poziom ekspresji ALCAM (cząsteczka aktywująca adhezję komórkową leukocytów) jest znacznie niższy w GC w porównaniu z NS [26].

\section{Rak piersi}

Liczne doniesienia świadczą o tym, że nowotwory piersi charakteryzują się zmienioną ekspresją wielu miRNA (tab. I - tylko w wersji elektronicznej artykułu). Według Mascellaniego i wsp. dotyczy to około 40 różnych miRNA - 23 rodzaje miRNA wykazują nadekspresję w komórkach nowotworowych, a w przypadku 14 rodzajów miRNA udowodniono ekspresję obniżoną [27]. Ekspresja wybranych miRNA jest ściśle skorelowana ze specyficznymi cechami biopatologicznymi nowotworu piersi, takimi jak ekspresja receptora estrogenowego i progesteronowego, stadium nowotworu, unaczynienie guza czy ilość i intensywność podziałów komórek [28]. Co więcej, poziom miRNA w komórkach uzależniony jest od stopnia zróżnicowania nowotworu, w słabo zróżnicowanych guzach jest on znacznie niższy [29].

Spośród wielu miRNA, których ekspresja jest zaburzona, badacze najczęściej wskazują kilka typów tych cząsteczek jako swoistych markerów raka piersi. Są nimi: miR-10b, miR-125b, miR-145, miR-21 i miR-155. Trzy z nich: miR-10b, miR-125b oraz miR-145 wykazują zmniejszoną ekspresję i mogą funkcjonować jako cząsteczki supresorowe. miR21 i miR-155 ulegają nadekspresji w nowotworach piersi, co może świadczyć o ich potencjalnej funkcji onkogennej. Genami docelowymi dla miR-10b są m.in. gen czynnika wzrostu BDNF (brain-derived neurotrophic factor) czy czynnika sygnalizacyjnego SHC1 (SHC transforming protein 1) [28]. miR-125b reguluje ekspresję licznych onkogenów, w tym genu receptora czynnika wzrostu FGFR2 (fibroblast growth factor receptor 2) czy genów kodujących białka szlaku sygnałowego zależnego od mitogenów, np. VTS58635 (RASL10B), MAP3K10, MAP3K11, MAPK14 [28]. Poza tym miR-125a i miR-125b kontrolują ekspresję genów receptorów kinaz tyrozynowych ERBB2 (v-erb-b2 erythroblastic leukemia viral oncogene homolog, HER2) i ERBB3 (HER3), a udowodniono, że wzmożona ekspresja lub amplifikacja HER2 jest wykrywana u około $30 \%$ chorych na raka piersi. Nadekspresja HER2 zaburza funkcjonowanie naturalnych mechanizmów kontrolnych cyklu komórkowego poprzez aktywowanie bądź represję szlaków przekazywania sygnałów wewnątrz komórek, skutkując bardziej agresywnym rozwojem nowotworu [30]. Locus genu miR-125b to 11 q23-24, jeden z regionów chromosomowych, które najczęściej ulegają delecji w nowotworach piersi [31], a brak cząsteczek miR-125 prawdopodobnie osłabia zdolność do różnicowania się komórek nowotworowych [32].

Cząsteczką o działaniu supresorowym i o obniżonej ekspresji w guzach piersi jest również miR-145. Kontroluje ona ekspresję takich onkogenów, jak np. MYCN (v-myc myelocytomatosis viral related oncogene), FOS (FBJ murine osteosarcoma viral oncogene homolog), YES (Yamaguchi sarcoma viral oncogene homolog) czy MAPK (mitogen-activated protein kinase), oraz genów kodujących białka sygnałowe, np. MAP3K3, MAP4K4 [28].

Najczęściej opisywanymi cząsteczkami miRNA wykazującymi nadekspresję w nowotworach piersi są miR-21 oraz miR-155 [28]. Zwiększona ekspresja związana jest prawdopodobnie z hamowaniem ekspresji genów supresorowych, co świadczy o onkogennym działaniu tych miRNA i ich roli w rozwoju guza. Gen miR-21 jest zlokalizowany na chromosomie 17q23, w regionie często ulegającym amplifikacji w nowotworach piersi, co skutkuje jego zwiększoną aktywnością [33]. Ekspresja miR-21, posiadającego właściwości antyapoptotyczne, jest indukowana hipoksją, co może być przejawem zdolności adaptacyjnych komórek do środowiska o zmniejszonej zawartości tlenu, które sprzyja przetrwaniu komórek nowotworowych [34]. Genem docelowym dla miR-21 jest m.in. gen supresorowy PTEN (phosphatase and tensin homolog) kodujący fosfatazę, która prowadzi do zahamowania wzrostu komórek oraz do zablokowania szlaków sygnałowych umożliwiających komórkom przetrwanie. Świadczy to o działaniu antyapoptotycznym tego miRNA [35]. Badania wykazały, że transfekcja hodowli komórek raka piersi oligonukleotydami anty-miRNA (AMOs) prowadzi do zahamowania aktywności miR-21, co w konsekwencji powoduje inhibicję wzrostu komórek in vitro, ich przyspieszoną apoptozę i obniżoną zdolność proliferacyjną [36]. Z kolei dla miR-155 genami docelowymi są supresory nowotworowe, takie jak SOCS1 (suppressor of cytokine signaling 1) i APC (adenomatous polyposis coli) [28].

Innym przykładem miRNA potencjalnie zaangażowanego w progresję nowotworu jest miR-9-3 o obniżonej ekspresji w raku piersi, związanym z naciekaniem naczyń 
iz występowaniem przerzutów do węzłów chłonnych. Wskazuje to na fakt, iż do obniżenia ekspresji dochodzi podczas progresji nowotworu, a w szczególności podczas nabywania zdolności do tworzenia przerzutów [28].

Bardzo istotną funkcję w hamowaniu rozwoju guza piersi pełni miR-205. Jego genem docelowym jest gen receptora HER3, a wykazano, że zwiększony poziom tego białka receptorowego jest oznaką agresywnych postaci nowotworu piersi [37].

Niewłaściwa ekspresja miRNA jest również powiązana ze zmianami w regulacji epigenetycznej, takimi jak stopień metylacji genów miRNA, co skutkuje modyfikacjami w poziomie ekspresji, np. miR-9-1 w przypadku raka piersi. W schorzeniu tym gen miR-9-1 podlega hipermetylacji prowadzącej do obniżenia ekspresji kodowanego miRNA [38].

\section{Nowotwory macicy}

Rak szyjki macicy jest drugim najczęściej przyczyniającym się do śmierci nowotworem wśród kobiet. Jest on wynikiem wielostopniowego procesu, obejmującego transformację prawidłowego nabłonka szyjki macicy do przednowotworowej śródbłonkowej neoplazji szyjki macicy, która następnie przekształca się w inwazyjny nowotwór [39]. Wśród czynników przyczyniających się do powstawania raka, poza zakażeniem papillomawirusem, coraz częściej wymieniane są czynniki genetyczne niezbędne do rozwoju złośliwych postaci nowotworu [39]. Ze względu na to naukowcy intensywnie poszukują markerów genetycznych, w tym zmian w ekspresji miRNA, które mogłyby być użyteczne w monitorowaniu i leczeniu chorych na raka szyjki macicy.

Spośród 157 rodzajów miRNA, których ekspresja badana była w tkankach raka szyjki macicy, Lee i wsp. wykazali znaczące różnice w przypadku 70 miRNA w porównaniu z prawidłowymi komórkami nabłonkowymi — aż 68 miRNA wykazywało nadekspresję, a tylko w przypadku 2 miRNA udowodniono ekspresję obniżoną. Zwiększona ekspresja dotyczyła przede wszystkim miR-9, miR-199a, miR-199b, miR-199s, miR-145, miR-133a, miR-133b, miR-127 oraz miR-214, a zmniejszona - miR-149 i miR-203 [40]. Naukowcy wykazali też, że podwyższona aktywność miR-127 jest ściśle związana z tworzeniem przerzutów do węzłów chłonnych. Zastosowanie oligonukleotydów anty-miR-199a pozwoliło na zahamowanie wzrostu komórek nowotworowych, co świadczy o tym, że miR-199a może stanowić cel molekularny $w$ terapiach celowanych raka szyjki macicy [40].

Inna grupa badawcza wyróżniła kilka typów miRNA o szczególnie podwyższonej ekspresji w komórkach raka szyjki macicy - miR-148a, miR-302b, miR-10a, miR-196a i miR-132 [41]. Cząsteczki miR-10a oraz miR-196a wpływają na aktywność genów HOX — rodziny czynników transkrypcyjnych kontrolujących procesy rozwojowe [42]. Gen kodujący miR-196a jest zlokalizowany w rzadkim miejscu łamliwym FRA12A, podobnie jak miR-148a i miR-302b, a cząsteczki te regulują przede wszystkim ekspresję supresorów nowotworowych, np. PTEN czy TP53 oraz innych genów kodujących białka zaangażowane w rozwój raka i jego progresję [41].

Ekspresja miRNA może stanowić również ważny czynnik prognostyczny w przebiegu raka szyjki macicy. Dzięki zastosowaniu metod opartych o technikę PCR udało się zidentyfikować miR-200a i miR-9 jako cząsteczki, których ekspresja prognozuje przeżycie chorego. Obydwie te cząsteczki odgrywają istotną rolę regulatorową w rozwoju raka szyjki macicy. W szczególności miR-200a wpływa na zdolność przerzutowania komórek nowotworowych poprzez kontrolowanie ich ruchliwości [43].

Łagodnym nowotworem macicy, w przebiegu którego również zaobserwowano zmiany w ekspresji miRNA, jest mięśniak gładkokomórkowy. Zaburzoną ekspresję miRNA wykazano zarówno w zależności od koloru skóry chorych kobiet, jak i wielkości guza. miR-23a/b, let-7, miR-145, miR-197, miR-411 i miR-412 odznaczają się znacznie większą nadekspresją u kobiet o ciemnym kolorze skóry w porównaniu z białymi kobietami dotkniętymi tym nowotworem. Wielkość guza wykazuje także związek z poziomem ekspresji miRNA, odnotowano to w przypadku 17 różnych typów tych cząsteczek, a ekspresja 5 miRNA należących do rodziny let-7 jest wyższa w małych guzach. Ponadto ekspresja miR-208, miR-339 oraz miR-381 różni się znacząco u chorych kobiet w zależności od ich wieku [44].

\section{Rak jelita grubego}

Spośród wielu rodzajów miRNA, których ekspresja w komórkach raka jelita grubego różni się znacząco od ekspresji w komórkach prawidłowych, na szczególną uwagę zasługują miR-143 i miR-145 o obniżonej ekspresji, a także miR-21, miR-31, miR-183, miR-17-5p, miR-20a oraz miR-92 o wyraźnie zwiększonej ekspresji w komórkach nowotworowych [45].

Dla cząsteczek miR-145 genem docelowym jest IRS-1 (insulin receptor substrate 1). Produktem tego genu jest białko adaptorowe dla receptora insulinopodobnego czynnika wzrostu i receptora insulinowego. Jest to jeden z czynników sygnalizacyjnych biorących udział w procesach antyapoptotycznych, mitogennych, niesprzyjających różnicowaniu. Właściwa ekspresja miR-145 wpływa na obniżenie poziomu IRS-1, i w konsekwencji hamuje wzrost ludzkich komórek raka jelita grubego [46]. W przypadku tego nowotworu zmniejszony poziom ekspresji dotyczy również miR-143, który poprzez regulację aktywności onkogenów wykazuje działanie supresorowe. miR-143 kontroluje ekspresję m.in. onkogenu K-RAS. Inhibicja ekspresji K-RAS skutkuje zahamowaniem konstytutywnej fosforylacji kinazy ERK1/2 i przyczynia się do zablokowania wzrostu komórek guza [47]. Kolejnym genem docelowym dla miR-143 jest DNMT3A [DNA(cytosine-5-)-methyltransferase 3 alpha], kodujący me- 
tylotransferazę DNA 3A. Wykazano, że przywrócenie ekspresji miR-143 w liniach komórkowych raka jelita grubego wydatnie hamuje wzrost komórek oraz zmniejsza ekspresję DNMT3A zarówno na poziomie mRNA, jak i białka [48].

W hamowanie aktywności onkogenów zaangażowany jest także miRNA let-7a-1, mający obniżoną ekspresję w wielu nowotworach. W liniach komórek raka jelita grubego transfekcja prekursora let-7a-1 prowadziła do spowolnienia wzrostu komórek oraz zmniejszonej ekspresji genów RAS i C-MYC [49]. Ekspresja genu K-RAS jest również blokowana przez miR-18a, którego represja prowadzi do zwiększenia aktywności proliferacyjnej komórek nowotworowych [50]. Działanie antyproliferacyjne w stosunku do komórek raka jelita grubego wykazuje także miR-34a. Wprowadzenie go do linii komórek nowotworowych skutkuje obniżoną ekspresją czynnika transkrypcyjnego E2F oraz zwiększonym poziomem białka TP53 [51].

Cząsteczką miRNA wykazującą działanie onkogenne w przebiegu wielu nowotworów jest miR-21. W komórkach raka jelita grubego miR-21 wykazuje podwyższony poziom ekspresji, przez co hamuje aktywność genu supresorowego PDCD4 [52]. Gen ten jest zaangażowany w hamowanie transformacji nowotworowej, inwazji oraz tworzenia przerzutów, a jego ekspresja w komórkach rakowych jest znacznie obniżona. Prowadzone badania wykazały odwrotną zależność między poziomami miR-21 i białka PDCD4 [52].

Podobna zależność została stwierdzona dla miR-31 - cząsteczki o działaniu onkogennym, której poziom jest wyższy w komórkach raka jelita grubego i w nowotworowych liniach komórkowych (w porównaniu z komórkami prawidłowymi). Poziom miR-31 jest związany ze stadium zaawansowania guza, co sugeruje, że ta cząsteczka może przyczyniać się zarówno do onkogenezy, jak i nabywania bardziej agresywnego fenotypu w przebiegu choroby. Przypuszczalnymi genami docelowymi dla miR-31 są geny czynników transkrypcyjnych FOXC2 (forkhead box C2) i FOXP3 (forkhead box P3) [53].

W komórkach raka jelita grubego, jak i w wielu innych nowotworach, mikroRNA o działaniu onkogennym jest też miR-183. Nadekspresja tej cząsteczki w komórkach nowotworowych prowadzi do obniżonego poziomu ekspresji istotnych genów supresorowych - EGR1 (early growth response 1) i PTEN. Utrata czynnika transkrypcyjnego EGR1 przekłada się na przyspieszoną transformację nowotworową i migrację komórek guza, a co za tym idzie — zwiększoną zachorowalność i śmiertelność [54]. Badania z wykorzystaniem macierzy miRNA dowiodły, że nadekspresji w komórkach rakowych jelita grubego ulega też miR-20a, co przyczynia się do zwiększonej aktywności przerzutowej komórek guza [55].

Zaobserwowano, że cząsteczki miRNA krążące we krwi mogą znaleźć zastosowanie jako potencjalne, nieinwazyjne markery molekularne dla monitorowania przebiegu raka jelita grubego. $\mathrm{Ng}$ i wsp. badali poziom ekspresji miRNA w osoczu chorych cierpiących na raka jelita grubego [56]. Udowodnili, że cząsteczki miR-92 oraz miR-17-3p wykazują wyraźnie podwyższony poziom u osób chorych. Co więcej, stwierdzono, że po chirurgicznym usunięciu guza ekspresja tych miRNA w osoczu ulega znaczącemu obniżeniu [56].

\section{Rak wątrobowokomórkowy}

Liczne dane z literatury wskazują na istnienie zdefiniowanych zmian we wzorach ekspresji miRNA dotyczących nowotworów złośliwych wątroby (tab. I - tylko w wersji elektronicznej artykułu). Jedną z cząsteczek regulatorowych specyficznych dla komórek wątroby jest miR-122. Zaobserwowano, że ekspresja tej cząsteczki jest znacząco obniżona $w$ raku wątroby ze zmianami wieloogniskowymi. Potencjalnym genem docelowym dla miR-122 jest ADAM17 (ADAM metallopeptidase domain 17) — istotny w tworzeniu przerzutów i aktywacji antyapoptotycznej sygnalizacji od receptora NOTCH1 [57]. Wyciszenie ADAM17 przez miR-122 skutkuje istotnym zmniejszeniem zdolności komórek nowotworowych do migracji in vitro, inwazji i onkogenezy in vivo [58].

Komórki nowotworowe wątroby wykazują także znacznie zredukowaną ekspresję miR-26a, która odznacza się dość dużą aktywnością w prawidłowych tkankach [59]. miR-26, hamując ekspresję genów kodujących cykliny D2 i E2, powoduje zatrzymanie cyklu komórkowego w fazie G1. Wprowadzenie tego miRNA do mysiego modelu komórek HCC (hepatocellular carcinoma) w wektorze wirusowym AAV doprowadziło do inhibicji proliferacji tych komórek poprzez indukowanie apoptozy oraz zapewniło ochronę przed dalszym rozwojem choroby bez niepożądanego efektu toksyczności [59].

miRNA o funkcji supresorowej, którego ekspresja jest wyraźnie obniżona w komórkach HCC, jest miR-126. Wykazano, że spadek poziomu ekspresji obserwowany jest w nowotworach związanych z nadmiernym spożywaniem alkoholu, a nie będących następstwem działania innych czynników hepatotoksycznych czy zakażenia wirusami hepatotropowymi [60]. Badania prowadzone na myszach, u których indukowano raka wątroby, ujawniły też obniżenie ekspresji genów kodujących takie cząsteczki, jak: miR-15/16, miR-34a, miR-150 i miR-195 [61].

Podwyższony poziom ekspresji w komórkach raka wątrobowokomórkowego stwierdzono m.in. w przypadku miR-221 oraz miR-222. Onkogenna rola miR-221 związana jest z hamowaniem ekspresji inhibitora P27 kinaz zależnych od cyklin oraz DDIT4 (DNA-damage-inducible transcript 4) - białka hamującego wzrost komórek poprzez regulację szlaku sygnałowego mTOR. miR-221 nie tylko stymuluje powstawanie nowotworu, lecz również przyczynia się do progresji choroby [62]. Z kolei cząsteczki miR-222 oddziałują na szlak sygnałowy AKT, a ich przypuszczalnym genem docelowym jest gen podjednostki B fosfatazy białkowej $2 \mathrm{~A}$. 
Nadekspresja miR-222 w komórkach HCC nadaje im zdolność przerzutowania poprzez aktywowanie szlaku AKT. Co więcej, udowodniono, że zwiększona ekspresja tego miRNA koreluje ze stopniem zaawansowania nowotworu i gorszymi rezultatami leczenia pacjentów cierpiących na HCC [63].

Jak wykazali Ji i wsp., komórki nowotworowe wątroby pozytywne pod względem ekspresji markera AFP (alfa-fetoproteina) cechują się wyraźną nadekspresją miR-181. Dodatkowo wysoki poziom ekspresji tego miRNA zaobserwowano w wątrobach zarodkowych i w wyizolowanych wątrobowych komórkach macierzystych. Genami docelowymi dla miR-181 są transkrypcyjne regulatory różnicowania, m.in. CDX2 (caudal homeobox 2) - gen homeotyczny kodujący czynnik transkrypcyjny oraz gen kodujący czynnik GATA6 (GATA binding protein 6) [64].

Innymi przykładami miRNA o funkcji onkogennej, których zwiększoną ekspresję wykazano w komórkach HCC, są miR-10b, miR-21, miR-224, miR-370 oraz klaster miR-17-92. Dla miR-224 genem docelowym jest API5, kodujący inhibitor apoptozy [65]. miR-370 wpływa natomiast na ekspresję $B A X$ (BCL-2-associated X protein) - genu proapoptotycznego, należącego do rodziny $B C L 2$, jednego z kluczowych regulatorów procesu apoptozy. Rodzina miR-17-92, składająca się z siedmiu rodzajów miRNA, kontroluje ekspresję czynnika transkrypcyjnego E2F1. Udowodniono, że komórki z transdukowanym miR-17-92 tworzą większe i bardziej inwazyjne nowotwory, a protoonkogen C-MYC, aktywujący transkrypcję tych miRNA, podtrzymuje produkcję czynnika wzrostu śródbłonka naczyniowego (VEGF), co może sugerować, że miR-17-92 nasilają efekt proangiogenny [66].

\section{Nowotwory ośrodkowego układu nerwowego}

Glejaki są jednymi z najczęściej spotykanych nowotworów OUN. Wywodzą się z komórek glejowych i stanowią 40-60\% guzów śródczaszkowych. Najczęstszym nowotworem złośliwym wywodzącym się z tkanki glejowej jest glejak wielopostaciowy, stanowiący nawet 90\% przypadków glejaków u osób dorosłych [67]. Guz ten cechuje się najwyższym stopniem złośliwości, a lokuje się najczęściej w płacie skroniowym i czołowym. Liczne doniesienia świadczą o tym, że nieprawidłowości w ekspresji wybranych miRNA mogą przyczyniać się do transformacji komórek glejowych, a tym samym do rozwoju nowotworu. Są to zarówno miRNA o funkcji supresorowej, jak i onkogennej (tab. I — tylko w wersji elektronicznej artykułu).

Cząsteczkami o działaniu supresorowym, których ekspresja jest znacznie obniżona w komórkach glejaka w porównaniu z prawidłowymi komórkami glejowymi, są miR-181a i miR-181b [68]. Wykazano, że te czynniki regulatorowe mają zdolność hamowania proliferacji, indukowania apoptozy oraz ograniczania inwazji komórek nowotworowych. Co więcej, indukowana nadekspresja miR-181a i miR-181b w komórkach glejaka skutkuje utratą zdolności komórek do wzrostu niezależnego od kontaktu z podłożem, który jest jednym z wyznaczników złośliwości komórek. Oznacza to, że miRNA z rodziny miR-181 funkcjonują jako supresory w komórkach glejaka [68]. Istotne znaczenie w rozwoju glejaka może mieć także obniżona ekspresja miR-34a. Cząsteczka ta, regulując ekspresję wielu onkogenów, np. C-MET i NOTCH, hamuje rozwój nowotworu. Udowodniono, że transfekcja linii komórek nowotworowych miR-34a prowadzi do zablokowania proliferacji i progresji cyklu komórkowego oraz obniża poziom przeżycia komórek i ich inwazyjność [69].

Działanie supresorowe w rozwoju glejaka, migracji i inwazji jego komórek wykazuje też miR-146b-5p [70]. Udowodniono, że ekspresja tego miRNA jest niższa we wszystkich typach glejaka niż w kontrolnych astrocytach. miR-146b-5p wiąże się do regionu 3'UTR transkryptu genu EGFR, powodując zahamowanie jego translacji. Wprowadzenie tego miRNA do komórek skutkuje zmniejszeniem poziomu fosforylacji kinazy białkowej (AKT) i zahamowaniem szlaku Pi3K/AKT. Świadczy to o tym, że przywrócenie prawidłowej ekspresji tego miRNA może być pomocne w leczeniu inwazyjnych form nowotworu [70]. EGFR jest genem docelowym także w przypadku miR-7, który wykazuje obniżoną ekspresję w komórkach glejaka. Stwierdzono, że funkcja miR-7 związana z hamowaniem szlaku AKT odpowiada za ograniczanie żywotności i inwazyjności nowotworu, co również świadczy o terapeutycznym potencjale tej cząsteczki [71].

Obniżona ekspresja w komórkach nowotworowych glejaka dotyczy też miR-124, miR-137 i miR-101. Cząsteczki miR-124 i miR-137 regulują ekspresję genu CDK6 i przyczyniają się do obniżenia poziomu białka CDK6, które zaangażowane jest w rozwój szeregu guzów złośliwych [72]. Skutkuje to blokadą cyklu komórkowego w fazie G1 i ograniczeniem proliferacji komórek glejaka wielopostaciowego, co może być niezwykle cenne w terapii tego schorzenia [72]. Również ekspresja miR-101 znacznie różni się w komórkach glejaka w porównaniu z komórkami niezmienionymi. Jak udowodnili Smits i wsp., niższy poziom tego miRNA powoduje niewystarczającą represję translacji mRNA genu EZH2 (enhancer of zeste homolog 2) [73]. Prowadzi to do nadekspresji metylotransferazy EZH2, która indukuje proliferację i migrację komórek guza oraz przyczynia się do rozwoju jego unaczynienia. Poziom ekspresji $E Z H 2$ koreluje z czasem przeżycia chorych [73].

miRNA o charakterze onkogennym, którego nadekspresja stwierdzana jest w wielu typach nowotworów, w tym w komórkach glejaka, jest miR-21 [74]. Miejsca wiążące dla tej cząsteczki odkryto w regionach 3'UTR transkryptów takich genów, jak: PDCD4, MTAP (methylthioadenosine phosphorylase) i SOX5 (sex determining region Y box 5). W rozwoju nowotworu bardzo istotnym jest PDCD4 - gen supresorowy zaangażowany $w$ apoptozę. W linii komórek glejaka T98G poziom ekspresji genu PDCD4 wykazuje odwrotną zależność w stosunku do ekspresji miR-21, a jego obniżenie 
prowadzi do zahamowania procesu apoptozy zależnej od tego genu [74]. Zwiększony poziom ekspresji w glejaku, w odniesieniu do prawidłowych komórek glejowych, dotyczy też miR-196. Udowodniono, że znaczna nadekspresja miR-196 w komórkach nowotworowych prawdopodobnie wiąże się z krótszym całkowitym czasem przeżycia chorych cierpiących na glejaka [75].

Innymi przykładami cząsteczek regulatorowych, których podwyższona ekspresja jest obserwowana w komórkach glejaka i w szeregu innych nowotworów, są miR-221 i miR-222. Kluczową ich rolą jest kontrola cyklu komórkowego i proliferacji poprzez regulację ekspresji białek P27 i P57. miR-221/222 biorą też udział w regulacji apoptozy przez bezpośrednie wiązanie się do regionu 3'UTR mRNA genu PUMA (BCL2 binding component 3) - uznanego niedawno za głównego mediatora apoptozy, w której bierze udział czynnik transkrypcyjny TP53 [76]. Zatem podwyższona ekspresja tych miRNA może przyczyniać się do zahamowania procesu zaprogramowanej śmierci komórki w przypadku glejaka. Zwiększona aktywność miR-221/222 w komórkach glejaka może wynikać z niewłaściwej ekspresji czynników transkrypcyjnych NF-kB (nuclear factor of kappa light polypeptide gene enhancer in B-cells) i C-JUN. Czynniki te, wiążąc się razem do jednego z regionów regulatorowych genów miR-221/222, indukują ich transkrypcję [77].

\section{Podsumowanie}

Zaburzenia ekspresji mikroRNA są istotnie związane ze zmianami zachodzącymi w komórkach podczas transformacji nowotworowej. Znaczna liczba cząsteczek miRNA zaangażowana w poszczególne procesy komórkowe sprawia, że obszar towarzyszących im badań jest bardzo rozległy, a nadzieje związane z wykorzystaniem ich w terapii celowanej nowotworów są bardzo duże. Jednakże skuteczne blokowanie lub suplementacja wybranych miRNA w terapii chorych na raka jest tematem niezwykle trudnym, wymagającym jeszcze wielu lat badań. Jest to spowodowane między innymi istnieniem wielu genów docelowych dla pojedynczych cząsteczek mikroRNA. Zatem hamując jeden szlak sygnałowy istotny w patogenezie nowotworu, można nieświadomie zaburzyć funkcjonowanie innych genów, co nie pozostanie bez konsekwencji dla przebiegu procesów komórkowych.

Nieprawidłowa ekspresja poszczególnych mikroRNA może wynikać ze zmian genomu, nieprawidłowości w ich biogenezie lub może mieć związek z epigenetycznymi czynnikami regulującymi ekspresję genów. Za przykład mogą posłużyć badania Vinci i wsp., którzy zwracają uwagę nie tylko na genetyczne przyczyny zmian ekspresji miRNA, takie jak polimorfizmy pojedynczych nukleotydów (SNP — single nucleotide polymorphisms) w genach miRNA, mające wpływ na transkrypcję i powstawanie pri-miRNA czy późniejsze interakcje pomiędzy dojrzałymi mikroRNA a mRNA, ale również na możliwość zmian w poziomie metylacji tych genów [78]. Istotne są zatem nie tylko strukturalnie uwarunkowane zmiany poziomu ekspresji miRNA, ale również ich epigenetyczna regulacja. Być może mechanizmy te staną się w przyszłości celem do opracowywania nowych terapii modulujących ekspresję miRNA poprzez zmiany w poziomie metylacji ich genów.

Warto zwrócić uwagę, że pewne cząsteczki mikroRNA mogą pełnić funkcje supresorów nowotworowych lub onkogenów w zależności od rodzaju nowotworu, tak jak w przypadku cząsteczek z rodziny miR-181 [64]. W komórkach HCC obserwuje się ich nadekspresję, natomiast w komórkach glejaka wykazują obniżony poziom ekspresji. Z tego powodu ważne jest badanie profili ekspresji miRNA i uwzględnianie ich przy diagnozowaniu i prognozowaniu przebiegu chorób nowotworowych.

Konflikt interesu: nie zgłoszono

\section{Mgr inż. Michał Budzyński}

Zakład Genetyki Nowotworów z Pracowniq Cytogenetyczna Uniwersytet Medyczny w Lublinie

ul. Radziwiłłowska 11, 20-950 Lublin

e-mail:micha_s20@interia.pl

Otrzymano: 11 kwietnia 2013 r.

Przyjęto do druku: 17 czerwca 2013 r.

\section{Piśmiennictwo}

1. Bartel DP. MicroRNAs: genomics, biogenesis, mechanism, and function. Cell 2004; 116: 281-297.

2. Izzotti A, Calin GA, Arrigo P i wsp. Downregulation of microRNA expression in the lungs of rats exposed to cigarette smoke. FASEB J 2009; 23: 806-812.

3. Calin GA, Sevignani C, Dumitru CD i wsp. Human microRNA genes are frequently located at fragile sites and genomic regions involved in cancers. Proc Natl Acad Sci USA 2004; 101: 2999-3004.

4. Esquela-Kerscher A, Slack FJ. Oncomirs - microRNAs with a role in cancer. Nat Rev Cancer 2006; 6: 259-269.

5. Zhu W, Liu X, He J i wsp. Overexpression of members of the microRNA-183 family is a risk factor for lung cancer: A case control study. BMC Cancer 2011; 11: 393.

6. Sarver AL, Li L, Subramanian S. MicroRNA miR-183 functions as an oncogene by targeting the transcription factor EGR1 and promoting tumor cell migration. Cancer Res 2010; 70: 9570-9580.

7. Wang G, Mao W, Zheng S. MicroRNA-183 regulates Ezrin expression in lung cancer cells. FEBS Lett 2008; 582: 3663-3668.

8. Yu Y, Khan J, Khanna C i wsp. Expression profiling identifies the cytoskeletal organizer Ezrin and the developmental homeoprotein Six21 as key metastatic regulators. Nat Med 2004; 10: 175-181.

9. Wang $X C$, Tian $L L$, Jiang $X Y$ i wsp. The expression and function of miRNA-451 in non-small cell lung cancer. Cancer Lett 2011; 311: 203-9.

10. Wang R, Wang ZX, Yang JS i wsp. MicroRNA-451 functions as a tumo suppressor in human non-small cell lung cancer by targeting ras-related protein 14 (RAB14). Oncogene 2011; 30: 2644-2658.

11. Shen J, Liu Z, Todd NW i wsp. Diagnosis of lung cancer in individuals with solitary pulmonary nodules by plasma microRNA biomarkers. BMC Cancer 2011; 11: 374

12. Li T, Li D, Sha J i wsp. MicroRNA-21 directly targets MARCKS and promotes apoptosis resistance and invasion in prostate cancer cells. Biochem Biophys Res Commun 2009; 383: 280-285.

13. Lee $\mathrm{KH}, \mathrm{Chen} \mathrm{YL}$, Yeh SD i wsp. MicroRNA-330 acts as tumor suppressor and induces apoptosis of prostate cancer cells through E2F1-mediated suppression of Akt phosphorylation. Oncogene 2009; 28: 3360-3370.

14. Mitchell PS, Parkin RK, Kroh EM i wsp. Circulating microRNAs as stable blood-based markers for cancer detection. Proc NatI Acad Sci USA 2008; 105: 10513-10518. 
15. Srivastava SK, Bhardwaj A, Singh S i wsp. MicroRNA-150 directly targets MUC4 and suppresses growth and malignant behavior of pancreatic cancer cells. Carcinogenesis 2011; 32: 183-1839.

16. Nagao $Y$, Hisaoka M, Matsuyama A i wsp. Association of microRNA-21 expression with its targets, PDCD4 and TIMP3, in pancreatic ductal adenocarcinoma. Mod Pathol 2012; 25: 112-121.

17. Bhatti I, Lee A, James V i wsp. Knockdown of microRNA-21 inhibits proliferation and increases cell death by targeting programmed cell death 4 (PDCD4) in pancreatic ductal adenocarcinoma. J Gastrointest Surg 2011; 15: 199-208.

18. Chambers AF, Matrisian LM. Changing views of the role of matrix metalloproteinases in metastasis. J Nat I Cancer Inst 1997; 89: 1260-1270.

19. Ballehaninna UK, Chamberlain RS. The clinical utility of serum CA 19-9 in the diagnosis, prognosis and management of pancreatic adenocarcinoma: An evidence based appraisal. $J$ Gastrointest Oncol 2012; 3: 105-119.

20. Liu J, Gao J, Du Y i wsp. Combination of plasma microRNAs with serum CA19-9 for early detection of pancreatic cancer. Int J Cancer 2012; 131: 683-691.

21. Pramanik D, Campbell NR, Karikari C i wsp. Restitution of tumor suppressor microRNAs using a systemic nanovector inhibits pancreatic cancer growth in mice. Mol Cancer Ther 2011; 10: 1470-1480.

22. Tseng CW, Lin CC, Chen CN i wsp. Integrative network analysis reveals active microRNAs and their functions in gastric cancer. BMC Systems Biology 2011; 5: 99

23. Guo SL, Peng Z, Yang X i wsp. miR-148a promoted cell proliferation by targeting p27 in gastric cancer cells. Int J Biol Sci 2011; 7: 567-574.

24. Kogo R, Mimori K, Tanaka F i wsp. Clinical significance of miR-146a in gastric cancer cases. Clin Cancer Res 2011; 17: 4277-4284.

25. Bou Kheir T, Futoma-Kazmierczak E, Jacobsen A i wsp. miR-449 inhibits cell proliferation and is down-regulated in gastric cancer. Mol Cancer 2011; 10: 29.

26. Jin Z, Selaru FM, Cheng Y i wsp. MicroRNA-192 and -215 are upregulated in human gastric cancer in vivo and suppress ALCAM expression in vitro. Oncogene 2011; 30: 1577-1585.

27. Mascellani N, Tagllavini L, Gamberoni G i wsp. Using miRNA expression data for the study of human cancer. Minerva Biotec 2008; 20: 23-30.

28. Iorio MV, Ferracin M, Liu CG i wsp. MicroRNA gene expression deregulation in human breast cancer. Cancer Res 2005; 65: 7065-7070.

29. Wang V, Wu W. MicroRNA: a new player in breast cancer development. J Cancer Mol 2007; 3: 133-138.

30. Kaufmann R, Muller P, Hildenbrand G i wsp. Analysis of Her2/neu membrane protein clusters in different types of breast cancers using localization microscopy. J Microsc 2010; 242: 46-54.

31. Negrini M, Rasio D, Hampton GM i wsp. Definition and refinement of chromosome 11 regions of $\mathrm{LOH}$ in breast cancer: identification of a new region at 11q23-q24. Cancer Res 1995; 55: 3003-3007.

32. Scott GK, Goga A, Bhaumik D i wsp. Coordinate suppression of ERBB2 and ERBB3 by enforced expression of microRNA miR-125a or miR-125b. J Biol Chem 2007; 282: 1479-1486.

33. Sinclair CS, Rowley M, Naderi A i wsp. The $17 q 23$ amplicon and breast cancer. Breast Cancer Res Treat 2003; 78: 313-322.

34. Negrini M, Ferracin M, Sabbioni S i wsp. MicroRNAs in human cancer: from research to therapy. J Cell Sci 2007; 120: 1833-1840.

35. Calin GA, Croce CM. MicroRNA signatures in human cancers. Nat Rev Cancer 2006; 6: 857-866.

36. Si ML, Zhu S, Wu H i wsp. miR-21-mediated tumor growth. Oncogene 2007; 26: 2799-2803.

37. Iorio MV, Casalini P, Piovan C i wsp. MicroRNA-205 regulates HER3 in human breast cancer. Cancer Res 2009; 69: 2195-2200.

38. Lehmann U, Hasemeier B, Christgen M i wsp. Epigenetic inactivation of microRNA gene hsa-mir-9-1 in human breast cancer. J Pathol 2008; 214: 17-24.

39. Di Saia PJ, Creasman WJ. Preinvasive disease of the cervix. W: Clinical Gynecologic Oncology. 6th ed. St. Louis CV: Mosby 2002; 1-34.

40. Lee JW, Choi $\mathrm{CH}$, Choi JJ i wsp. Altered microRNA expression in cervical carcinomas. Clin Cancer Res 2008; 14: 2535-2542.

41. Pereira PM, Marques JP, Soares AR i wsp. MicroRNA expression variability in human cervical tissues. PLoS One 2010; 5: e11780.

42. Abate-Shen C. Deregulated homeobox gene expression in cancer: cause or consequence? Nat Rev Cancer 2002; 2: 777-785.

43. Hu X, Schwarz JK, Lewis JS Jr i wsp. A microRNA expression signature for cervical cancer prognosis. Cancer Res 2010; 70: 1441-1448.

44. Wang $T$, Zhang $X$, Obijuru L i wsp. A microRNA signature associated with race, tumor size, and target gene activity in human uterine leiomyomas. Genes Chromosomes Cancer 2007; 46: 336-447.
45. Motoyama $\mathrm{K}$, Inoue $\mathrm{H}$, Takatsuno $\mathrm{Y}$ i wsp. Over- and under-expressed microRNAs in human colorectal cancer. Int J Oncol 2009; 34: 1069-1075.

46. Shi B, Sepp-Lorenzino L, Prisco M i wsp. MicroRNA-145 targets the insulin receptor substrate- 1 and inhibits the growth of colon cancer cells. J Biol Chem 2007; 282: 32582-32590.

47. Chen X, Guo X, Zhang H i wsp. Role of miR-143 targeting KRAS in colorectal tumorigenesis. Oncogene 2009; 28: 1385-1392.

48. Ng EK, Tsang WP, Ng SS i wsp. MicroRNA-143 targets DNA methyltransferases 3A in colorectal cancer. Br J Cancer 2009; 101: 699-706.

49. Fang WJ, Lin CZ, Zhang HH i wsp. Detection of let-7a microRNA by real-time PCR in colorectal cancer. J Int Med Res 2007; 35: 716-723.

50. Tsang WP, KwokTT. The miR-18a* microRNA functions as a potential tumor suppressor by targeting on K-Ras. Carcinogenesis 2009; 30: 953-959.

51. Tazawa H, Tsuchiya N, Izumiya M i wsp. Tumor-suppressive induces senescence-like growth arrest through modulation of the E2F pathway in human colon cancer cells. Proc Natl Acad SciUSA 2007; 104: 15472-1547.

52. Asangani IA, Rasheed SA, Nikolova DA i wsp. MicroRNA-21 (miR-21) post-transcriptionally downregulates tumor suppressor $\mathrm{Pdcd} 4$ and stimulates invasion, intravasation and metastasis in colorectal cancer. Oncogene 2008; 27: 2128-2136.

53. Bandrés $E$, Cubedo E, Agirre X i wsp. Identification by real-time PCR of 13 mature microRNAs differentially expressed in colorectal cancer and non-tumoral tissues. Mol Cancer 2006; 5: 29.

54. Sarver AL, Li L, Subramanian S. MicroRNA miR-183 functions as an oncogene by targeting the transcription factor and promoting tumor cell migration. Cancer Res 2010; 70: 9570-9580.

55. Fan X, Liu Y, Jiang J i wsp. miR-20a promotes proliferation and invasion by targeting APP in human ovarian cancer cells. Acta Biochim Biophys Sin 2010; 42: 318-324.

56. Ng EK, Chong WW, Jin $\mathrm{H}$ i wsp. Differential expression of microRNAs in plasma of patients with colorectal cancer: a potential marker for colorectal cancer screening. Gut 2009; 58: 1375-1381.

57. Bray SJ. Notch signaling: a simple pathway becomes complex. Mol Cell Biol 2006; 7: 678-689.

58. Tsai WC, Hsu PW, Lai TC i wsp. MicroRNA-122, a tumor suppressor microRNA that regulates intrahepatic metastasis of hepatocellular carcinoma. Hepatology 2009; 49: 1571-82.

59. Kota J, Chivukula RR, O'Donnell KA i wsp. Therapeutic microRNA delivery suppresses tumorigenesis in a murine liver cancer model. Cell 2009; 137: 1005-1017.

60. Ladeiro Y, Couchy G, Balabaud Ci wsp. MicroRNA profiling in hepatocellular tumors is associated with clinical features andoncogene/tumor suppressor gene mutations. Hepatology 2008; 47: 1955-1963.

61. Chang TC, Yu D, Lee YS i wsp. Widespread microRNA repression by Myc contributes to tumorigenesis. Nat Genet 2008; 40: 43-50.

62. Pineau P, Volinia S, McJunkin K i wsp. miR-221 overexpression contributes to liver tumorigenesis. Proc Natl Acad Sci USA 2009; 107: 264-269.

63. Wong QW, Ching AK, Chan AW i wsp. MiR-222 overexpression confers cell migratory advantages in hepatocellular carcinoma through enhancing AKT signaling. Clin Cancer Res 2010; 16: 867-875.

64. Ji J, Yamashita T, Budhu A i wsp. Identification of microRNA-181 by genome-wide screening as a critical player in EpCAM-positive hepatic cancer stem cells. Hepatology 2009; 50: 472-480.

65. Wang Y, Lee AT, Ma JZ i wsp. Profiling microRNA expression in hepatocellular carcinoma reveals microRNA-224 up-regulation and apoptosis inhibitor-5 as a microRNA-224-specific target. J Biol Chem 2008; 283: 13205-13215.

66. Dews M, Homayouni A, Yu D i wsp. Augmentation of tumor angiogenesis by a Myc-activated microRNA cluster. Nat Genet 2006; 38: 1060-1065.

67. Turkowski K. Rola chirurgicznego leczenia glejaków mózgu. Ann Univ Mariae Curie Skłodowska 2005; 60: 7.

68. Shi L, Cheng Z, Zhang J i wsp. hsa-mir-181a and hsa-mir-181b function as tumor suppressors in human glioma cells. Brain Res 2008; 1236: 185-193.

69. Li Y, Guessous F, Zhang Y i wsp. MicroRNA-34a inhibits glioblastoma growth by targeting multiple oncogenes. Cancer Res 2009; 69: 7569-7576.

70. Katakowski M, Zheng $\mathrm{X}$, Jiang F i wsp. MiR-146b-5p suppresses EGFR expression and reduces in vtro migration and invasion of glioma. Cancer Invest 2010. 28: 1024-30.

71. Kefas B, Godlewski J, Comeau L i wsp. microRNA-7 inhibits the epidermal growth factor receptor and the Akt pathway and is down-regulated in glioblastoma. Cancer Res 2008; 68: 3566-3572.

72. Silber J, Lim DA, Petritsch C i wsp. miR-124 and miR-137 inhibit proliferation of glioblastoma multiforme cells and induce differentiation of brain tumor stem cells. BMC Med 2008; 6: 14. 
73. Smits M, Nilsson J, Mir SE i wsp. miR-101 is down-regulated in glioblastoma resulting in $\mathrm{EZH} 2$ - induced proliferation, migration, and angiogenesis. Oncotarget 2010; 1: 710-720.

74. Chen Y, Liu W, Chao T i wsp. MicroRNA-21 down-regulates the expression of tumor suppressor PDCD4 in human glioblastoma cell T98G. Cancer Lett 2008; 272: 197-205.

75. Guan Y, Mizoguchi M, Yoshimoto K i wsp. MiRNA-196 is upregulated in glioblastoma but not in aplastic astrocytoma and has prognostic significance. Clin Cancer Res 2010; 16: 4289-4297.
76. Zhang CZ, Zhang JX, Zhang AL i wsp. MiR-221 and miR-222 target PUMA to induce cell survival in glioblastoma. Mol Cancer 2010; 9: 229.

77. Galardi S, Mercatelli N, Farace MG i wsp. NF-kB and c-Jun induce the expression of the oncogenic miR-221 and miR-222 in prostate carcinoma and glioblastoma cells. Nucleic Acids Res 2011; 39: 3892-3902.

78. Vinci S, Gelmini S, Mancini I i wsp. Genetic and epigenetic factors in regulation of microRNA in colorectal cancers. Methods 2013; 59: 138-146.

W dniu 4 października 2014 r. odbędzie się w Warszawie

Konferencja Naukowo-Szkoleniowa

"Czerniak i inne nowotwory skóry — postępy w diagnostyce i leczeniu"

Organizatorzy:

Polskie Towarzystwo Chirurgii Onkologicznej

Akademia Czerniaka - Sekcja PTChO działająca pod patronatem Polskiego Towarzystwa Onkologii Klinicznej

i Polskiego Towarzystwa Dermatologicznego

Centrum Onkologii — Instytut im. Marii Skłodowskiej-Curie w Warszawie

Przewodniczący Komitetu Naukowego i Organizacyjnego:

prof. dr hab. med. Piotr Rutkowski

Miejsce obrad:

Radisson Blu Sobieski Warsaw

Plac Zawiszy 1, 02-025 Warszawa

Informacje i zgłoszenia: http://www.dermatoonkologia2014.skolamed.pl/ 